\title{
Analysis Of The Effect Of The Rupiah Exchange, World Oil Price, World Gold Price On The Joint Stock Price Index In The Indonesia Stock Exchange
}

\author{
Suniti Rohmawati ${ }^{1}$, Munasirotul Mutmainnah ${ }^{2}$, Fitria Asas ${ }^{3 *}$, Ulfatul Khasanah ${ }^{4}$ \\ 1,2 Student Of Accounting, Faculty Of Economics, \\ Permata Islamic Economics College Bojonegoro Jawa Timur Indonesia. \\ ${ }^{3,4}$ Departement Of Accounting, Faculty Of Economics, \\ Permata Islamic Economics College Bojonegoro Jawa Timur Indonesia. \\ * Corresponding author: \\ Email: fitriaasas@gmail.com
}

\begin{abstract}
.
Stock price fluctuations that could be traded on the stock exchange can be seen from JCI Indonesia so that we can know whether the market is bullish (strong) or bearish (weak). All in result by 2 factors, internal factors and eksternal. Many theory of past research revealed that the composite stock price index is influenced by several factors. Three factors including the value of the rupiah, world gold prices, and world oil prices. Because other than gold commodity rupiah exchange rate and the oil will affect the movement of stock indices on the StockExchange. The study population was the entire data rupiah exchange rate, oil prices and gold prices on the world in 2011-2014 and since such data exist today (historical price). This study uses statistical analisisis, Multiple linear regression, and the $F$ test and $T$ and test (coefficient of determination (R2)), Normality Test, Test Heteroskidastity. Based on hypothesis testing shows that world oil prices and world gold prices have a negative effect and no significant effect on the JCI while the rupiah / US \$has a positive and significant impact on JCI.
\end{abstract}

Keywords: JCI, macroeconomics, Hypothesis testing

\section{INTRODUCTION}

Overall economic development can be seen from the development of the capital market and securities industry in a country. As the executor of economic functions, the capital market provides facilities for transferring funds from parties with excess funds to parties in need of funds. Investment activities are activities to invest directly or indirectly with the hope that in due time the owner of the capital will get a number of benefits from the results of the investment (Samsul, 2008: 40).

One indicator of a country's macroeconomic success is the composite stock price index (CSPI) in addition to the interest rate, exchange rate and GNP factors. If the economic condition of a country is good, the JCI will of course also show an increasing trend, but if the economic condition of a country is in a downturn, it will also affect the JCI. The following is a table containing JCI data between 2017-2020. 
Table 1. Composite Stock Price Index Development Year 2017-2020

\begin{tabular}{|c|c|c|}
\hline Year & JCI & Development (\%) \\
\hline 2017 & 3942 & 15,64 \\
\hline 2018 & 4317 & 9,51 \\
\hline 2019 & 4274 & $-1,00$ \\
\hline 2020 & 5227 & 22,30 \\
\hline
\end{tabular}

Source:http://www.bi.go.id/id/Default.aspx (23/09/2020)

The table above shows that the JCI in 2017-2020 fluctuated (increased and decreased). In 2018 the JCI was 4317 then in 2019 the JCI fell by $1 \%$ and in 2020 it rose again by $22.30 \%$. With the information revolution, investors everywhere can observe the JCI at the same time. According to Ruhendi and Arifin (2003:54) the currency exchange rate shows the price of a currency when it is exchanged with other currencies, where the exchange rate can be interpreted as a comparison of values between currencies. Determination of the exchange rate of a country's currency with the currency of another country is determined as well as goods, namely by the demand and supply of the currency in question.

Currently, the industry in Indonesia is experiencing a period of growth. These companies actively carry out export and import activities. One of the factors that facilitated export and import activities was the existence of currency as a means of transaction. One of the currencies commonly used in international trade is the United States Dollar. For companies that actively carry out export and import activities, the stability of the dollar exchange rate against the rupiah is important. Because when the value of the rupiah depreciates against the United States dollar, this will result in imported goods being expensive. If most of the company's raw materials use imported materials, this will automatically result in an increase in production costs. This increase in production costs will certainly reduce the company's profit level. The decline in the level of company profits will certainly affect investors' buying interest in the shares of the company concerned. In general, this will encourage the weakening of the stock price index in the country (witjaksono, 2016: 55).

\section{METHODS}

\section{Research Approach}

The type of research used in this study uses the type of explanatory research. Research according to the level of explanation is research that intends to explain the position of the variables studied and the relationship between one variable and other variables (sangadji and sopiah 2016: 2)

\section{Research object}

The research object of this thesis is at the IDX Surabaya Office which is located at Jl. Basuki Rahmat No. 46 Surabaya 


\section{Population and Sampling Techniques}

The population used in this study is all JCI data, the effect of the Dollar Exchange on the Rupiah, World Oil Prices (based on West Texas Intermediate standards), World Gold Prices. Based on data available on the internet for all the variables used in this study, data is available from $2017-2020$.

The sample of this study was taken after fulfilling several criteria that apply to the application of the operational definition of variables. The sampling technique used in this study is the purposive sampling method, namely the sample is drawn using considerations. The criteria for selecting the sample to be studied are as follows:

a. Composite Stock Price Index (JCI). Data obtained from the official website http://www.idx.co.id. The data used is data at the end of each month during the observation period between 2017-2020.

b. Rupiah exchange rate. The exchange rate used is the middle rate of the rupiah against the United States dollar issued by Bank Indonesia. Exchange rate data is taken from the official website http://www.bi.go.id/id/Default.aspx. The data used is the value of the selling rate at the end of the month during the observation period between 2017-2020.

c. World Oil Prices In this study, the world oil prices used are the West Texas Intermediate standard. World oil price data is taken from http://www.research.stlouisfed.org. The data used is data at the beginning of each month during the observation period between 2017-2020.

d. World Gold Price The gold price used is the closing gold price in the afternoon (P.M Gold price). The world gold price data is taken from http://www.hargaemas.net. The data used is the average monthly gold price during the observation period between 2017-2020

The reason for choosing the year period used is to get more accurate results according to the current situation. The selection of monthly data is to avoid bias that occurs due to market panic in reacting to information, so that the use of monthly data is expected to obtain more accurate results.

\section{Data Collection Method}

The data collection method used is by collecting, recording, and reviewing secondary data originating from the official website of Bank Indonesia with the website address www.bi.go.id, world oil prices are obtained from the official website for world oil standard prices West Texas Intermediate with the website address www.research.stlouisfed.org, the world gold price is obtained from the official website of the world gold price with the website address http://www.harga-emas.net.

\section{Operational Definition}

The following is the operational definition of the variables used in this study:

a. Composite Stock Price Index

The Jakarta Composite Index, JCI, or JSX Composite is one of the stock market indexes used by the Indonesia Stock Exchange (IDX). First introduced on April 
1, 1982, as an indicator of stock price movements on the IDX, this index covers the price movements of all common shares and preferred shares listed on the IDX.

b. Rupiah Rate

The rupiah exchange rate is an agreement known as the currency exchange rate against current or future payments, between the two currencies of each country or region.

c. World Oil Prices

The world oil price is the world price of crude oil which is measured from the spot price of the world oil market. Currently the benchmark for crude oil prices commonly used is West Texas Intermediate (WTI) or light-sweet. Crude oil traded on West Texas Intermediate (WTI) is high quality crude oil (useconomy.about.com).

d. World Gold Price

The world gold price is the standard price of the London gold market which is used as a benchmark for world gold prices. Where the system used is known as London Gold Fixing. The price determination process is carried out twice a day, at 10.30 (Gold A.M) and 15.00 (Gold P.M). The following is a table of operational measurements along with the measurement of each ratio:

e. Population and Sample

The population used in this study is all JCI data, the effect of the Dollar Exchange on the Rupiah, World Oil Prices (based on West Texas Intermediate standards), World Gold Prices. Based on data available on the internet for all the variables used in this study, data is available from $2017-2020$.

f. Analysis Method

In this research, the research method used is Multiple Linear Regression analysis, $\mathrm{F}$ and $\mathrm{T}$ test, $\mathrm{R} \rrbracket \wedge 2$ determinant test, normality test, heteroscedasticity test.

\section{RESULT AND DISCUSSION \\ Data Presentation}

The Indonesian Stock Exchange, abbreviated as BEI, or the Indonesia Stock Exchange (IDX), is the result of the merger of the Jakarta Stock Exchange (JSX) and the Surabaya Stock Exchange (BES). For the sake of operational effectiveness and transactions, the government decided to merge the Jakarta Stock Exchange as a stock market with the Surabaya Efel Exchange as a bond and derivatives market. The resulting stock exchange began operating on December 1, 2007.

IDX has used a trading system called the Jakarta Automated Trading System (JATS) since May 22, 1995, replacing the manual system that was previously used, since March 2, 2009 the JATS system itself has been replaced with a new system called JATS-NextG provided by OMX. The Indonesia Stock Exchange is based in the Indonesia Stock Exchange building, Sudirman commercial area, Jalan Jenderal Sudirman 52-53, Senayan, Kebayoran Baru, South Jakarta. 


\section{Stock Price Index}

The stock price index is an indicator or reflection of stock price movements. The index is one of the guidelines for investors to invest in the capital market, especially stocks. In 2015, the Indonesia Stock Exchange had 11 types of stock price indexes which were continuously disseminated through print and electronic media.

The index indexes are:

a. Composite Stock Price Index (JCI)

b. Sectoral Index

c. LQ45 Indeks Index

d. Jakarta Islamic Index (JII)

e. Compass Index 100

f. Business Index-27

g. Pefindo25 Indeks Index

h. SRI-Healthy Index

i. Main Board Index

j. Development Board Index

Of all these indices, in this study the index used is the Composite Stock Price Index (IHSG). Using all listed companies as components of the index calculation. In order for the JCI to describe a fair market condition, the Indonesia Stock Exchange has the authority to exclude or exclude one or several listed companies from the JCI calculation. The basis for consideration is, among other things, if the number of shares of the listed company owned by the public (free float) is relatively small while the market capitalization is large enough, so that changes in the share price of the listed company have the potential to affect the fairness of the JCI movement. JCI is owned by the Indonesia Stock Exchange. The Indonesia Stock Exchange is not responsible for products issued by users who use the JCI as a benchmark (benchmark). The Indonesia Stock Exchange is also not responsible in any way for investment decisions made by anyone by anyone who uses the JCI as a benchmark (benchmark). The independent variable in this study is the JCI. JCI is a composite stock price index issued by the Indonesian stock exchange every day. JCI data obtained directly from http://www.bi.go.id/id/Default.aspx The data used is data at the end of each month during the observation period between 2017-2020

Table 2. List of Composite Stock Price Index 2017-2020

\begin{tabular}{|l|l|l|l|}
\hline Month & JCI & Month & JCI \\
\hline January 2017 & $3.409,17$ & January 2018 & $3.941,69$ \\
\hline February 2017 & $3.470,35$ & February 2018 & $3.985,21$ \\
\hline March 2017 & $3.678,67$ & March 2018 & $4.121,55$ \\
\hline April 2017 & $3.819,62$ & April 2018 & $4.180,73$ \\
\hline May 2017 & $3.836,97$ & May 2018 & $3.832,82$ \\
\hline June 2017 & $3.888,57$ & June 2018 & $3.955,58$ \\
\hline July 2017 & $4.130,80$ & July 2018 & $4.142,34$ \\
\hline
\end{tabular}




\begin{tabular}{|l|l|l|l|}
\hline August 2017 & $3.841,73$ & August 2018 & $4.060,33$ \\
\hline September 2017 & $3.549,03$ & September 2018 & $4.262,56$ \\
\hline October 2017 & $3.790,85$ & October 2018 & $4.350,29$ \\
\hline November 2017 & $3.715,08$ & November 2018 & $4.276,14$ \\
\hline December 2017 & $3.821,99$ & December 2018 & $4.316,69$ \\
\hline January 2019 & $4.453,70$ & January 2020 & $4.418,76$ \\
\hline February 2019 & $4.795,79$ & February 2020 & $4.620,22$ \\
\hline March 2019 & $4.940,99$ & March 2020 & $4.768,28$ \\
\hline April 2019 & $5.034,07$ & April 2020 & $4.840,15$ \\
\hline May 2019 & $5.068,63$ & May 2020 & $4.893,1$ \\
\hline June 2019 & $4.818,90$ & June 2020 & $4.878,58$ \\
\hline July 2019 & $4.610,38$ & July 2020 & $5.088,80$ \\
\hline August 2019 & $4.195,09$ & August 2020 & $5.136,86$ \\
\hline September 2019 & $4.316,18$ & September 2020 & $5.137,58$ \\
\hline October 2019 & $4.510,63$ & October 2020 & $5.089,55$ \\
\hline November 2019 & $4.256,44$ & November 2020 & $5.149,89$ \\
\hline December 2019 & $4.212,22$ & December 2020 & $5.160,433$ \\
\hline
\end{tabular}

Source http://www.bi.go.id/id/Default.aspx (23/09/2020)

\section{Rupiah Rate}

The Rupiah exchange rate is the exchange rate of the rupiah against the United States dollar. The exchange rate used is the middle rate of the rupiah against the United States dollar issued by the Indonesian bank. Exchange rate data is taken from www.bi.go.id. The data used is the value of the selling rate at the end of the month during the 2017-2020 observation period. It can be described as follows:

Table 3. Rupiah Exchange Rate Data for 2017-2020

\begin{tabular}{|c|c|c|c|}
\hline Month & Kurs Rupiah & Month & Kurs Rupiah \\
\hline January 2017 & Rp. 9.698 & January 2018 & Rp. 12.226 \\
\hline February 2017 & Rp. 9.667 & February 2018 & Rp. 11.634 \\
\hline March 2017 & Rp. 9.719 & March 2018 & Rp. 11.404 \\
\hline April 2017 & Rp. 9.722 & April 2018 & Rp. 11.532 \\
\hline May 2017 & Rp. 9.802 & May 2018 & Rp. 11.611 \\
\hline June 2017 & Rp. 9.929 & June 2018 & Rp. 11.969 \\
\hline July 2017 & Rp. 10.278 & July 2018 & Rp. 11.591 \\
\hline August 2017 & Rp. 10.924 & August 2018 & Rp. 11.717 \\
\hline September 2017 & Rp. 11.613 & September 2018 & Rp.12.212 \\
\hline October 2017 & Rp. 11.234 & October 2018 & Rp. 12.082 \\
\hline November 2017 & Rp. 11.977 & November 2018 & Rp. 12.196 \\
\hline December 2017 & Rp. 12.189 & December 2018 & Rp. 12.440 \\
\hline January 2019 & Rp. 9.698 & January 2020 & Rp. 12.226 \\
\hline February 2019 & Rp. 9.667 & February 2020 & Rp. 11.634 \\
\hline
\end{tabular}




\begin{tabular}{|l|l|l|l|}
\hline March 2019 & Rp. 9.719 & March 2020 & Rp. 11.404 \\
\hline April 2019 & Rp. 9.722 & April 2020 & Rp. 11.532 \\
\hline May 2019 & Rp. 9.802 & May 2020 & Rp. 11.611 \\
\hline June 2019 & Rp. 9.929 & June 2020 & Rp. 11.969 \\
\hline July 2019 & Rp. 10.278 & July 2020 & Rp. 11.591 \\
\hline August 2019 & Rp. 10.924 & August 2020 & Rp. 11.717 \\
\hline September 2019 & Rp. 11.613 & September 2020 & Rp.12.212 \\
\hline October 2019 & Rp. 11.234 & October 2020 & Rp. 12.082 \\
\hline November 2019 & Rp. 11.977 & November 2020 & Rp. 12.196 \\
\hline December 2019 & Rp. 12.189 & December 2020 & Rp. 12.440 \\
\hline
\end{tabular}

Source: http//www.bi.go.id/id/moneter/informasi-kurs (23/09/2020)

\section{World Oil Prices}

World Oil Price is the spot price of the world oil market which is formed from the accumulation of supply and demand. In this study, the price of oil used is the West Texas Intermediate standard. World oil price data is taken from http://www.research.stlouisfed.org The data used is data at the end of each month during the 2017-2020 observation period. As seen in the following list:

Table 4. World Oil Price Data for 2017-2020

\begin{tabular}{|c|c|c|c|}
\hline Month & Oil price & Month & Oil price \\
\hline January 2017 & Rp. 809.152 & January 2018 & Rp. 896.040 \\
\hline February 2017 & Rp. 863.595 & February 2018 & Rp. 9970.260 \\
\hline March 2017 & Rp. 917.928 & March 2018 & Rp. 945.723 \\
\hline April 2017 & Rp. 976.835 & April 2018 & Rp. 964.306 \\
\hline May 2017 & Rp. 858.736 & May 2018 & Rp. 869.075 \\
\hline June 2017 & Rp. 783.702 & June 2018 & Rp. 805.420 \\
\hline July 2017 & Rp. 814.215 & July 2018 & Rp. 854.883 \\
\hline August 2017 & Rp. 732.303 & August 2018 & Rp. 922.253 \\
\hline September 2017 & Rp. 675.021 & September 2018 & Rp. 883.917 \\
\hline October 2017 & Rp. 824.482 & October 2018 & Rp. 922.582 \\
\hline November 2017 & Rp. 887.380 & November 2018 & Rp. 853.980 \\
\hline December 2017 & Rp. 896.190 & December 2018 & Rp. 887.899 \\
\hline January 2019 & Rp. 833.964 & January 2020 & Rp. 1.191.912 \\
\hline February 2019 & Rp. 900.287 & February 2020 & Rp. 1.193 .532 \\
\hline March 2019 & Rp. 944.978 & March 2020 & Rp. 1.158 .532 \\
\hline April 2019 & Rp. 904.146 & April 2020 & Rp. 1.217.779 \\
\hline
\end{tabular}




\begin{tabular}{|l|c|l|c|}
\hline May 2019 & Rp. 901.489 & May 2020 & Rp. 1.191.283 \\
\hline June 2019 & Rp. 958.744 & June 2020 & Rp. 1.265 .242 \\
\hline July 2019 & Rp. 1.076 .106 & July 2020 & Rp. 1.190 .859 \\
\hline August 2019 & Rp. 1.175 .968 & August 2020 & Rp. 1.124 .363 \\
\hline September 2019 & Rp. 1.194.624 & September 2020 & Rp. 1.142.310 \\
\hline October 2019 & Rp. 1.099.629 & October 2020 & Rp. 973.084 \\
\hline November 2019 & Rp. 1.110.507 & November 2020 & Rp. 806.765 \\
\hline December 2019 & Rp. 1.199.641 & December 2020 & Rp. 680.841 \\
\hline
\end{tabular}

source: http://www.research.stlouisfed.org (23/09/2020)

\section{World Gold Price}

The world gold price is the spot price formed from the accumulation of supply and demand in the London gold market. The world gold price data is taken from http://www.harga-emas.net. The data used is the average monthly gold price during the observation period between 2017-2020. As seen in the following list.

Table 5. World Gold Price 2017-2020

\begin{tabular}{|c|c|c|c|}
\hline Month & Gold Price & Month & Gold Price \\
\hline January 2017 & Rp. 521.000 & January 2018 & Rp. 521.000 \\
\hline February 2017 & Rp. 545.000 & February 2018 & Rp. 546.000 \\
\hline March 2017 & Rp. 502.000 & March 2018 & Rp. 525.000 \\
\hline April 2017 & Rp. 482.000 & April 2018 & Rp. 517.000 \\
\hline May 2017 & Rp. 475.000 & May 2018 & Rp. 508.000 \\
\hline June 2017 & Rp. 465.000 & June 2018 & Rp. 504.000 \\
\hline July 2017 & Rp. 458.000 & July 2018 & Rp. 515.000 \\
\hline August 2017 & Rp. 511.000 & August 2018 & Rp. 521.000 \\
\hline September 2017 & Rp. 475.000 & September 2018 & Rp.536.000 \\
\hline October 2017 & Rp. 517.000 & October 2018 & Rp. 522.000 \\
\hline November 2017 & Rp. 536.000 & November 2018 & Rp. 527.000 \\
\hline December 2017 & Rp. 497.00 & December 2018 & Rp. 487.500 \\
\hline January 2019 & Rp. 521.000 & January 2020 & Rp. 489.000 \\
\hline February 2019 & Rp. 495.000 & February 2020 & Rp. 496.000 \\
\hline March 2019 & Rp. 482.000 & March 2020 & Rp. 494.000 \\
\hline April 2019 & Rp. 470.000 & April 2020 & Rp. 493.000 \\
\hline May 2019 & Rp. 458.000 & May 2020 & Rp. 492.000 \\
\hline June 2019 & Rp. 458.000 & June 2020 & Rp. 510.000 \\
\hline July 2019 & Rp. 458.000 & July 2020 & Rp. 510.000 \\
\hline August 2019 & Rp. 507.000 & August 2020 & Rp. 511.000 \\
\hline September 2019 & Rp. 511.000 & September 2020 & Rp. 505.000 \\
\hline October 2019 & Rp. 492.000 & October 2020 & Rp. 487.000 \\
\hline November 2019 & Rp. 490.000 & November 2020 & Rp. 471.000 \\
\hline December 2019 & Rp. 474.000 & December 2020 & Rp. 482.000 \\
\hline
\end{tabular}

Source: http://www.harga-emas.net. (23/09/2020) 


\section{Data Analysis}

In this study, the analysis used is Multiple Linear Regression Test between Macroeconomic Variables partially or simultaneously on the Composite Stock Price Index on the IDX. The next stage is to perform multiple linear regression, $\mathrm{F}$ and $\mathrm{T}$ tests, Normality test, and Heteroscedasticity test. To determine the relationship and influence of variable X (Rupiah Exchange Value, World Oil Price, World Gold Price) with the Composite Stock Price Index on the IDX. For example, in table 4.5, the results of the SPPS processing and processing for multiple Linear Regression are given the effect of the Rupiah Exchange Rate as X1, World Oil Prices as X2, and World Gold Prices as X3, on the Composite Stock Price Index.

Table 6. F. Test Results

ANOVA $^{b}$

\begin{tabular}{|l|l|l|l|c|l|}
\hline Model & Sum of squares & Df & Mean Square & F & Sig \\
\hline 1 Regresi on & 7232420,496 & 3 & 2410806,832 & 20,683 &, $000^{\mathrm{a}}$ \\
\hline Residual & 5128512,696 & 44 & 116557,107 & & \\
\hline Total & $1,236 \mathrm{E} 7$ & 47 & & & \\
\hline $\begin{array}{l}\text { a.Predictors: (Constant), World Gold Price (X3), Rupiah Exchange Rate (X1), World Oil } \\
\text { Price (X2) } \\
\text { b.Dependent Variable: ISHG (Y) }\end{array}$ \\
\hline
\end{tabular}

\section{Source: Appendix Data}

From the ANOVA test or F test, the calculated $\mathrm{F}$ is 20,683 with a significance level of 0.000 because the probability $(0.000)$ is smaller than 0.05 , so the regression model can be used to predict the Composite Stock Price Index. Or it can be said that the Rupiah Exchange Rate, World Oil Prices and World Gold Prices together have an effect on the Composite Stock Price Index. So that the hypothesis which states "The Rupiah Exchange Rate, World Oil Prices and World Gold Prices have a simultaneous effect on the JCI on the IDX in the period 2017-2020." It can be accepted because it can be proven by a probability value of $0.000<0.05$ significant value.

Table 7. T . Test Results

\begin{tabular}{|c|c|c|c|c|c|}
\hline \multirow[t]{2}{*}{ Model } & \multicolumn{2}{|c|}{$\begin{array}{c}\text { Unstandardized } \\
\text { Coefficients }\end{array}$} & \multirow{2}{*}{$\begin{array}{c}\text { Standardized } \\
\text { Coefficients } \\
\text { Beta }\end{array}$} & \multirow[t]{2}{*}{$\mathrm{t}$} & \multirow[t]{2}{*}{ Sig. } \\
\hline & B & std. eror & & & \\
\hline 1 (Constant) & 4332,188 & 1165,354 & & 3,717 & ,001 \\
\hline $\begin{array}{l}\text { Rupiah Exchange Rate } \\
\text { (X1) }\end{array}$ & ,266 &, 039 & ,678 & 6,840 &, 000 \\
\hline World Oil Prices (X2) & $-2,062$ & 4,955 &,- 041 &,- 416 & 679 \\
\hline World Gold Price (X3) &,- 005 & ,002 &,- 251 & $-2,539$ &, 015 \\
\hline
\end{tabular}

\section{Source: Appendix Data}

The results of the research hypothesis on the influence of the Rupiah exchange rate, world oil prices, world gold prices on the JCI will be partially discussed as follows: 
a. From the regression equation above, it can be seen that the t-count value of the Rupiah exchange rate is 6.840 with a significance level of 0.000 . Because the significance value is less than $5 \%$ and the t-count value is 6.840 , there is a significant positive effect between the Rupiah Exchange Rate variable on the JCI. So that when the Rupiah exchange rate rises, the Composite Stock Price index also increases.

b. From the regression equation above, it can be seen that the t-count value of World Oil Prices is -416 with a significance level of 0.679 . Because the significance value is less than $5 \%$ and the $\mathrm{t}$-count value is $-416>\mathrm{t}$ table, there is a significant negative effect between the World Oil Price variable on the JCI. So when the World Oil Price decreases, the Composite Stock Price Index increases.

c. From the regression equation above, it can be seen that the t-count value of the World Gold Price is -2.539 with a significance level of 0.015 . Because the significance value is greater than $5 \%$ and the $\mathrm{t}$ value is $-2.539<\mathrm{t}$ table, there is an insignificant negative effect between the World Gold Price variable on the Composite Stock Price Index. So when the World Gold Price increases, the index decreases.

Table 4.3. Determinant Coefficient Test Results

Model Summary

\begin{tabular}{|l|l|l|l|l|l|}
\hline Model & \multicolumn{1}{|c|}{$\mathrm{R}$} & $\mathrm{R}$ Square & $\begin{array}{l}\text { Adjusted } \\
\text { Square }\end{array}$ & $\begin{array}{l}\text { Std. Error of the } \\
\text { Estimate }\end{array}$ \\
\hline 1 &, $765^{\mathrm{a}}$ &, 585 &, 557 & 341,4046085 & \\
\hline
\end{tabular}

a.Predictors: (Constant), World Gold Price (X3), Rupiah Exchange Rate (X1), World Oil Price (X2)

b.Dependent Variable: ISHG (Y)

\section{Source: Appendix Data}

The coefficient of determination $\left(\mathrm{R}^{\wedge} 2\right)$ measures how far the model's ability to vary the dependent variable. The value of the coefficient of determination is between zero and one. A small $\mathrm{R}^{\wedge} 2$ value means the ability of the independent variable to explain the dependent variable is very limited. A value close to one means that the independent variable provides almost all the information needed to predict the variation of the dependent variable. Shows the correlation coefficient $(R)$ and the coefficient of determination (Rsquare). The value of $\mathrm{R}$ describes the level of relationship between the independent variable $(\mathrm{X})$ and the dependent variable $(\mathrm{Y})$. From the results of the attached data, the correlation coefficient value is $55 \%$, meaning the relationship between variable $\mathrm{X}$ (Rupiah exchange rate, world oil prices, world gold prices) to variable Y (JCI).

$\mathrm{R}$ square explains how much variation in $\mathrm{Y}$ is caused by $\mathrm{X}$, from the calculation results obtained $\mathrm{R} 2$ of 0.765 or $76.5 \%$, meaning that the Composite Stock Price index is influenced by the rupiah exchange rate, world oil prices, and world gold prices. While the remaining $33.5 \%$ is influenced by other factors outside the 
model.From these results, it can be concluded that the Rupiah exchange rate has a significant effect on the Composite Stock Price Index, while the World Oil Price and world gold prices have no partial significant effect on the Composite Stock Price Index.

\section{Normality Test}

This test aims to test whether in the regression model, the confounding or residual variables have a normal distribution. This test uses the Normal P-lot graph as shown in Figure 1. Based on the figure that spreads around the diagonal line and follows the direction of the diagonal line, the regression model assumes normality.

\section{Fig 1.}

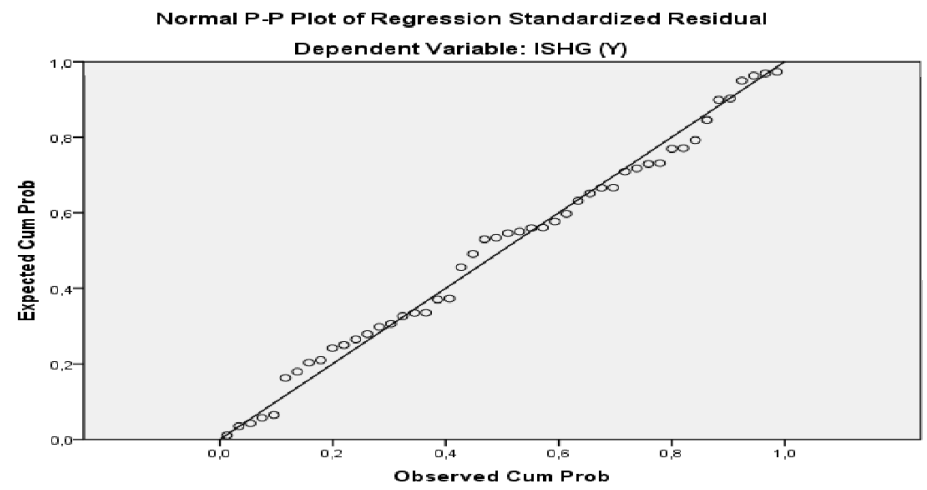

\section{Heteroscedasticity Test}

This test is carried out to test whether in a regression model there is an inequality of variance from the residuals of one observation to another. A good regression model is that there is no heteroscedasticity. Tests can use a scatterplot on the regression test that has been done. It can be seen from Figure 2 shows that the visible dots do not form a certain pattern. So it can be concluded that there is no symptom of heteroscedasticity so that the regression model used is appropriate to be used to predict the dependent variable based on the input of the independent variable.

Fig 2.

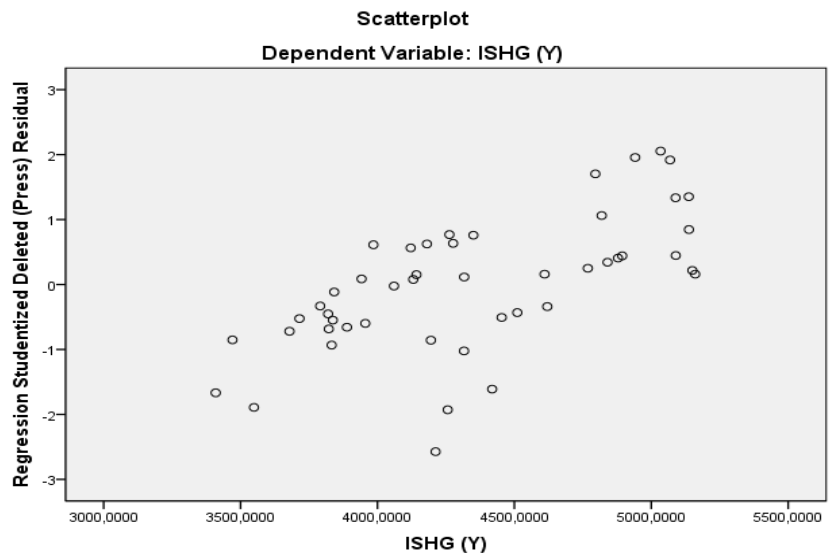




\section{Discussion}

From the results of hypothesis testing, it is shown that partially the Rupiah Exchange Rate, World Oil Price and World Gold Price have no significant effect on the Composite Stock Price Index. The results of testing hypotheses 1 to 3 can be described as follows:

a. The Rupiah Exchange Rate (X1) has a significant positive effect on the Composite Stock Price Index (Y).

Any increase or decrease in the Rupiah Exchange rate has a significant effect on the Composite Stock Price Index. The results of the regression analysis to test the direct effect of the rupiah exchange rate on the Composite Stock Price Index of 6.840 and having a sig.t of $0.000(0.000,<0.05)$, it can be concluded that the rupiah exchange rate variable has a significant positive effect on the Composite Stock Price Index. This is not in accordance with the research conducted by Ruhendi and Arifin.

b. World Oil Price (X2) has no significant negative effect on the Composite Stock Price Index (Y).

Any increase or decrease in the World Oil Price does not have a significant effect on the Composite Stock Price Index. The results of the regression analysis to examine the direct effect of the World Oil Price variable on the Composite Stock Price Index of -416 and having a Sig.t of $0.679(0.679>0.05)$, it can be concluded that the world rupiah exchange rate variable has a negative and insignificant effect on the index. This Joint Stock Price is in accordance with research conducted by Valadkhani et al, Ruhendi and Arifin and Rusbariandi

c. World Gold Price (X3) has a significant negative effect on the Composite Stock Price Index (Y)

The existence of an increase or decrease in each point in the World Gold Price does not have a significant effect on the composite stock price index. The results of the regression analysis to test the direct effect of the Composite Stock Price variable are -2.539 and have Sig. $t$ is $0.015(0.015<0.5)$, it can be concluded that the rupiah exchange rate has a relatively small and significant positive effect on the Composite Stock Price Index. This is in accordance with research conducted by Ruhendi and Arifin and Rusbariandi.

\section{CONCLUSION}

This study aims to determine the effect of the rupiah exchange rate, world gold prices, world oil prices with dimensions of increase or decrease on the composite stock price index on the Indonesia Stock Exchange (period 2017-2020) and to find out which variables have the most influence. From the formulation of the problem proposed, the data analysis that has been carried out and the discussion that has been stated in the previous chapter can be drawn some conclusions as follows: 
1. Based on multiple linear regression testing and research hypotheses, it is known that the rupiah exchange rate variable partially, the Rupiah exchange rate (X1) has a significant positive effect on the Composite Stock Price Index (Y). However, simultaneously (simultaneously) the Rupiah Exchange, World Oil Prices and World Gold Prices have a simultaneous effect on the JCI on the IDX in the 20172020 period.

2. Based on multiple linear regression testing and research hypotheses, it is known that the World Oil Price variable partially, World Oil Price (X2) has a negative and insignificant effect on the Composite Stock Price Index (Y). However, simultaneously (simultaneously) the Rupiah Exchange, World Oil Prices and World Gold Prices affected the JCI on the IDX in the 2017-2020 period.

3. Based on multiple linear regression testing and research hypotheses, it is known that the World Gold Price variable partially, World Gold Price (X3) has a negative and insignificant effect on the Composite Stock Price Index (Y). However, simultaneously (simultaneously) the Rupiah Exchange, World Oil Prices and World Gold Prices affected the JCI on the IDX in the 2017-2020 period.

\section{ACKNOWLEDGMENTS}

The author thanks the leadership of the foundation who has financed and supported this research, to fellow lecturers and employees of the Islamic Economics High School, Permata Bojonegoro, for their invaluable advice.

\section{REFERENCES}

[1] Budi et al (2020). "Manajemen portofolio dan investasi"salemba empat Jakarta.

[2] Cristiawan (2016).”Harga saham di pasarkan secara signifikan”, penerbit : Pt.Tempo Inti Media Harian.

[3] Hirschey dan Nofsionger (2008)." Teori analisa dan kebijakan” gramedia pustaka, Jakarta.

[4] Jogiyanto (2009). "Teori portofolio dan analisis investasi.edisi keenam. Cetakan pertama yogyakarta : BPFE.

[5] Kewal, S Suci (2018)."Pengaruh inflasi, suku bunga, kurs dan pertumbuhan PDB terhadap IHSG", jurnal economi, volume 8, no 1.

[6] Kilian dan Park (2007)."The Impact of Oil Price Shocks on the U.S. Stock Market ,International Economic Review”. Vol.50, no.4 hal.62-78.

[7] Muharam dan nurafni (2008)."Analisis pengaruh nilai tukar Rupiah terhadap Dollar Amerika dan indeks dow jones terhadap IHSG". jurnal maksi Fakultas ekonomi Universitas Dipenogoro.

[8] Ruhendi dan Arifin (2003). "Dampak Perubahan Kurs Rupiah dan Indeks Harga Saham Dow Jones di New York Stock Exchange terhadap Indeks Harga Saham Gabungan di Bursa Efek Jakarta ."Wahana,Vol 6,no 1 hal.45-55. 
[9] Rusbariandi (2018). “Analisis pengaruh Tingkat Inflasi, Harga Minyak Dunia, Harga Emas Dunia dan Kurs Rupiah terhadap Jakarta Islamic Index di Bursa Efek Indonesia pada periode Januari 2005 - Maret 2018”.Vol 8,no 12 hal 22-4.

[10] Sangadji, Etta Mamang., sopiah. 2016. Metodologi Penelitian Pendekatan Praktis dalam Penelitian. Yogyakarta: Andi.

[11] Samsul Muhammad (2008). "Pasarmodal dan manajemen portofolio". Jakarta: Erlangga.

[12] Sangadji, Etta mamang, Sopiah 2016. Metodologi penelitian pendekatan praktis dalam penelitian. Yogyakarta.

[13] Situs resmi Bank Indonesia http:// www.bi.go.id diambil pada tanggal 23/09/2016.

[14] Situs resmi harga emas dunia http://www.harga-emas.net. Diambil pada tanggal 23/09/2016.

[15] Situs resmi harga standar minyak dunia http://www.research.stlouisfed.org, diambil pada tanggal 23/09/2016.

[16] Triyono (2008). "Analisis perubahan kurs rupiah terhadap Dollar amerika”. Jurnal ekonomi pembangunan.Vol 9, no 2, 156-157 Fakultas ekonomi universitas Muhammadiyah Surakarta.

[17] Undang-Undang Republik Indonesia No. 8 Tahun 1995 tentang Pasar Modal,

[18] Valadkhani et al (2006). "The Inter play Between the Thai and Several Other International Stock Markets". Vol 24, no.2 hal 241-256.

[19] Wijaksono (2016)."Analisis tingkat suku bunga SBI, Harga minyak dunia, mekanisme dan perdagangan efek dari pasar modal" (sumber buku panduan indeks ).

[20] Witjaksono (2016). "Analisis Pengaruh Tingkat Suku Bunga SBI, Harga Minyak Dunia, Harga Emas Dunia, Kurs Rupiah, Indeks Nikkei 225, dan Indeks Dow Jones terhadap IHSG”.Vol.12,no 24 hal 121-154. 